\title{
FDI Asymmetries in Emerging Economies: The Case of Colombia
}

\author{
Jose U. Mora Mora ${ }^{1} \&$ Celso J. Costa Junior ${ }^{2}$ \\ ${ }^{1}$ Pontificia Universidad Javeriana - Cali, Colombia \\ ${ }^{2}$ State University of Ponta Grossa and School of Economics - Getúlio Vargas Foundation, Brazil \\ Correspondence: Jose U. Mora, Department of Economics, Pontificia Universidad Javeriana - Cali, Av. Cañas \\ Gordas (calle 18) \# 118 -250, Edificio El Lago, FCEA, Santiago de Cali, Valle del Cauca, zip: 760031, Colombia. \\ Tel: 57-3321-8200 Ext 9055. E-mail: jose.mora@javerianacali.edu.co
}

Received: May 9, 2019

Accepted: June 22, 2019

Online Published: June 25, 2019

doi:10.5539/ijef.v11n8p35

URL: https://doi.org/10.5539/ijef.v11n8p35

\begin{abstract}
We build a DSGE model to study the asymmetries of FDI shocks in an economy like Colombia. Besides nominal wage and price rigidities, we use the fact that Colombia has two productive and differentiated regions, Bogota that produces more than $25 \%$ of Colombia GDP (DANE, 2016) and the rest of the country, Ricardian and non-Ricardian agents, habit formation, capital adjustment costs, and modeled an entire foreign sector. Empirical results show that even when in the long run results are not very different in terms of real output, the short run effects are asymmetric implying that a shock to FDI in the rest of the country might cause important microeconomic adjustments that could improve the distribution of income throughout the country.
\end{abstract}

Keywords: DSGE models, Bayesian estimation, FDI

\section{Introduction}

Despite the political difficulties associated with drug-traffic and the armed conflict that have severely affected Colombia for several decades, the decision of taking the path towards a more open and free market economy have brought significant changes to Colombians during the last twenty years. Perhaps not all the benefits are getting to those in most need yet, but this process might be the foundation for a progressive reduction of the asymmetries in income distribution and social exclusion problems in the long run.

The definitive abandonment of the import substitution model and the "Ley 7 de 1991" changed of direction of the Colombian economy (Solano, 2013). Despite the 2008 crisis, the Colombian economy has been steadily growing, with ups and downs in its economic activity, but growing without severe inflation problems. According to the main macroeconomic indicators from the Administrative Department for National Statistics, DANE, and Banco de la República, between 2000 and 2017 per-capita GDP grew at $2.71 \%$ with the highest growth rate of $5.6 \%$ in 2007 and the lowest of $0.45 \%$ in 2009. Likewise, the inflation rate, although oscillating, has been progressively diminishing, from its highest value of $7.67 \%$ in December 2008 to $1,76 \%$ in November 2013; however, it has increased again to $8.97 \%$ in July 2016.

The unemployment rate has also been falling from $13.1 \%$ in January 2008 to reach $8.6 \%$ in December 2017. The exchange rate has had wide swings, falling first from 2965.6 in January 2003 to 1761.0 in January 2013, increasing to 3009.53 pesos per dollar in December 2016, and finally having a small fall to 2984 pesos per dollar in December 2017. The trade balance has been in deficit since early 2000s showing a significant increase in exports and imports which has raised the degree of openness of the economy. This, of course, has worsened the current account but, on the other hand, the capital account has improved because of the increasing foreign direct investment (FDI) and net acquisition of liabilities leaving a net surplus in the balance of payments. These effects are the result of important changes in economic policy and of the several trade agreements that Colombia has signed with several trading partners during the last 15 years.

In June 2012, Colombia, jointly with Mexico, Peru, and Chile, signed the agreement for the creation of the Pacific Alliance. This agreement seeks to promote the free trade in goods, services, capital, and people within the country members in order to stimulate the competitiveness of their products and their economic growth and development. This agreement tries to improve their trade connections with the Asian basin countries. It is expected that this integration would bring not only more trade among its members, but also more foreign direct investment (FDI) with the adhesion of Mexico to the Integrated Latin American Market (MILA) that was also 
created in parallel to the Pacific Alliance. But the fall in oil prices in 2014 affected the Colombian economy and, since then, fiscal authorities and Banco de la Republica, the central bank of Colombia, have been trying to reduce its impact on the overall economic activity. The amount of foreign investment that was expected to come to the country has decreased since most of FDI were targeted to oil and other mining activities. However, more recently, Colombia has been making progress towards important institutional changes, for instance the peace agreement placed into effect in 2016, that could increase foreign direct investment in the next years.

In this direction, this paper aims to investigate whether or not there are asymmetric effects within the regions and the overall effects on aggregate economic activity in Colombia. To accomplish this task, we have constructed a dynamic stochastic general equilibrium (DSGE) model different in several aspects from the ones from Rincon-Castro et al. (2014) and Gonzalez et al. (2011). Particularly, our model allows us to study the microeconomic impacts among two regions of Colombia: Bogota and the rest of the country. Given the fact that Bogota produces approximately 25\% of Colombian GDP (DANE, 2016), we believe that FDI investment may cause effects on each region that may not by symmetrical at all.

Results indicate that depending of the FDI receiving region of the country, FDI might have asymmetric results on overall economic activity. If FDI is spread out uniformly within the country, we will observe only small changes in the short run, but then capital, labor, inputs, and final good markets will adjust, and the economy will return to its steady state by the end of the simulation period. Next, if a positive FDI shock occurs in Bogota, the economy contracts in the short run, slowly recovers, and finally reaches a steady higher level of real output. Nevertheless, if the FDI innovation occurs in the rest of the country, then the economy experiences a boom in the short run, and then slowly contracts until it reaches its steady state. We show that FDI directed to the rest of the country might induce important microeconomic adjustments in the input and goods markets.

Finally, this paper is organized as follows. The next section presents a review of the literature on DSGE models for Colombia and their main findings. Section three presents the model. Section four discusses the calibration and how the model reproduces the main characteristics of the Colombian economy. Next, empirical results are presented and discussed in section five. And, finally, section six concludes.

\section{Literature Review}

Despite the criticism that argues that DSGE models use wrong micro foundations (ignore elements from behavioral economics), the lack of criteria for the selection of moments to evaluate the model and the lack of a well defined statistic to measure the goodness of fit (Stiglitz, 2017), DSGE models have been widely used in the literature by several central banks or economic authorities to evaluate the impacts induced by changes in economic policies, namely fiscal, monetary, financial regulations, and so on, on real economic activity. In Colombia, although the literature is still scarce, there are several important contributions using this methodology that have been produced during the last years.

Before turning the attention to the literature of DSGE Models, it is important to mention the paper of Gomez-Gonzalez et al. (2012) who pointed out that the relationship between capital flows and financial stability in Colombia is not strong. They, using a VAR approach, show that capital flows did not cause the increase in either the domestic credit or the overall economic activity in Colombia during the period 1995 and 2011; however, they found an indirect relationship between these two variables that works through the ratio of loans to GDP.

The Colombian central bank, Banco de la Republica, as many other central banks throughout the world, has been using the model Policy Analysis Tool Applied to Colombian Needs, also known as the PATACON model (Gonzalez et al., 2013) to perform policy analysis and determine the economic implications before making any monetary policy decision.

Lopez (2014) extend the model of Bernanke and Gertler (1999) to a small open economy to compare whether their results hold in a small open economy like Colombia. Contrary to the closed case, the model assumes financial market imperfections and a floating exchange rate regime. Results suggest that in the presence of capital inflows and if the central bank does not react to the increase in asset prices but to inflation, then output fluctuations are greater than in the closed economy. Their explanation is that capital inflows causes an appreciation of domestic currency that causes a higher response of market asset prices that induce an increase in investment.

The model of Lopez (2016) examines the effects of fiscal policy in a small open economy considering the balance sheet effects on investment. Lopez finds that when government spending increases, interest rate rises and, as a result, the price of capital falls. This causes also a fall in the net worth of entrepreneurs negatively affecting 
investment. So, the potency of fiscal policy is reduced. In the same way, Rincon-Castro et al. (2014) evaluate the impacts that several fiscal shocks have on the main macroeconomic variables and analyze how fiscal and monetary policy interact with one another. They find that in the presence of an increase in government spending, the output effects depend on whether fiscal policy is temporary or permanent. This also causes different monetary policy reactions.

Gonzalez et al. (2013) show that a structural fiscal rule delivers a better outcome in terms of macroeconomic volatility relative to a balanced budget rule or a countercyclical fiscal rule. They use a DSGE model with Non Ricardian agents, price and wage ridigities and the fact that the government finances, at least partly, government spending with public debt. Our model is different in that there are pensioned and non-pensioned Non-Ricardian households and that we use two different regions within the country believing that FDI shocks may propagate differently among them. Our model uses nominal price and wage rigidities as suggested by Bonaldi, Gonzalez, and Rodriguez (2010).

Several other models have been built to address other economic phenomena such as productivity and monetary shocks as the the model of Díaz (2012), the relationship between employment and real output as in Gonzalez et al. (2011) or the interaction between real and financial variables as in Valencia, Osorio, and Garay (2016). Díaz (2012), assuming Colombia is a small closed economy, considers nominal and wage rigidities and Ricardian and non-Ricardian agents who offer two different types of labor to study the effects of productivity and monetary shocks. Results are in accord with the ones found in the literature.

The model from Gonzalez et al. (2011) show that although in some countries, i.e. U.S.A., the relationship between employment and real output tends to be stable in the long run, empirical evidence for Colombia suggest that positive changes in output may not be followed by the level of employment. They found that fluctuations induced by technology innovations, and that increase multifactor productivity, do not get transmitted with enough force to aggregate demand and as a result produce less incentives for employment to increase. This happens, they argued, because the higher demand can be supplied by the increase in productivity. On the contrary, non-technology innovations create aggregate demand increases that, in absence of technological improvements, cause an increase in employment due to the need to fulfill the higher aggregate demand.

Finally, Valencia, Osorio, and Garay (2016) in a closed economy set up, that considers not only nominal price and wage ridigities but also financial frictions, investigates the relationship between real and financial variables before productivity, monetary and financial shocks. Results show that monetary shocks induce output contractions; productivity shocks rise the cost of external financing, and, finally, financial shocks (defaults for instance) lead to output contractions. These results imply that the greater the fragility of the financial system, the wider the swings of economic activity.

These models share common elements. Some of them are addressed to the analysis of the impacts of capital inflows, others consider the effects of fiscal policy on the economy and how monetary react to it, and others study diverse phenomena, different from what study. In our model we consider, first, spatial differentiation of firms by considering two regions: Bogota and the rest of the country. Second, the production function of intermediate firms considers not only labor and capital but also foreign direct investment. Third, there are adjustment cost to capital and three types of households: Ricardian with habit formation, non-Ricardian non-Pensioned, and non-Ricardian pensioned. And, finally, we model the foreign sector considering foreign households, firms and authorities. By doing so, this will allow us to study not only employment, wages, and resource allocations but also how output might change along time at the aggregate level and in both regions.

\section{The Model}

We assume that Colombia is a small open economy that takes world prices as given, has a flexible exchange rate regime, and participates in the world financial market (medium capital mobility).

In this paper, we follow very closely the model from Costa Junior, Garcia-Cintado, and Vaz Sampaio (2016) who developed a model for Brazil to study the effects of Brazilian fiscal policy after 2008. Our model is not very different from the later and from the other ones, except that, as we mentioned previously, we assume that the economy has two productive sectors and two different regions: center (Bogota) and the periphery (rest of the country). The reasons by doing so is because we want to compare the macroeconomic and microeconomic effects of FDI in different parts of the country. First, according to the National Accounts by state published by DANE (2016) the Bogota metropolitan region produces around one fourth of Colombian GDP. Second, foreign direct investment is used to finance capital accumulation in the domestic economy. So, intermediate firms can employ both domestic and foreign capital. As a result, to study the effects of foreign direct investment on the economy, we assumed a shock on foreign capital that follows an AR(1) process. Third, we use Non-Ricardian 
and Ricardian agents with habit formation, but the former is also divided into two groups: those who work, pay for social security and pensions, and may be eligible to receive net transfers from the government, and those who only receive net transfers and pensions from the government.

\subsection{Households}

There are two types of households: Non-Ricardian and Ricardian. Both consume only the domestic good, which means that there are no imported final goods. All imports are of capital or intermediate goods. The fraction of Ricardian household consumption in aggregate consumption is given by $\varpi_{R}$ and, thus, aggregate consumption equals

$$
C_{t}=\varpi_{R} C_{R, t}+\left(1-\varpi_{R}\right) C_{N R, t}
$$

Non-Ricardian households can be divided as well in two groups: Non-Pensioned and Pensioned. Aggregate consumption for Non-Ricardian agents is computed as follows:

$$
C_{N R, t}=\varpi_{N R}^{p} C_{N R, t}^{P}+\left(1-\varpi_{N R}^{p}\right) C_{N R, t}^{N P}
$$

Substituting back into the previous equation, we get:

$$
C_{t}=\varpi_{R} C_{R, t}+\left(1-\varpi_{R}\right) \varpi_{N R}^{p} C_{N R, t}^{P}+\left(1-\varpi_{R}\right)\left(1-\varpi_{N R}^{p}\right) C_{N R, t}^{N P}
$$

The pensioned Non-Ricardian agents are retired, receive net transfers and pensions from the government, and consume up to the limit given by these resources as equation (1) shows:

$$
\left(1+\tau_{t}^{c}\right) P_{t} C_{N R, t}^{P}=P E N_{t}
$$

Where $\tau_{t}^{c}$ is the consumption tax rate and $P_{t}$ is the price of aggregate output, $Y_{t}$. The non-pensioned Non-Ricardian agents are those who work, pay for social security, and consume up to the limit given by their current income from work and government net transfers. However, due to their liquidity constraints, they do not save. As a result, a non-pensioned Non-Ricardian agent must solve the following optimization problem.

$$
\max _{C_{N R, t}^{N P} ; L_{N R, t}} E_{t} \sum_{t=0}^{\infty} \beta^{t} S_{t}^{p}\left\{\frac{\left(C_{N R, j, t}^{N P}-\phi_{C} C_{N R, j, t-1}^{N P}\right)^{1-\sigma}}{1-\sigma}-S_{t}^{L}\left[\frac{L_{N R, j, t}^{1+\varphi}}{1+\varphi}\right]\right\}
$$

subject to her budget constraint given by:

$$
\left(1+\tau_{t}^{c}\right) P_{t} C_{N R, t}^{N P}=\left(1-\tau_{t}^{l}\right) W_{t} L_{N R, t}
$$

The first order condition gives us the following result:

$$
\left(1+\tau_{t}^{c}\right) P_{t} \lambda_{N R, t}=S_{t}^{P}\left(C_{N R, t}^{N P}-\varphi_{c} C_{N R, t-1}^{N P}\right)^{-\sigma}-\varphi_{c} E_{t} \beta\left[S_{t+1}^{P}\left(C_{N R, t+1}^{N P}-\varphi_{c} C_{N R, t}^{N P}\right)^{-\sigma}\right]
$$

Ricardian agents exhibit consumption habit and must find the optimal consumption and labor paths in order to maximize the present value of their expected utility.

$$
\max _{C_{R, j, t} ; U_{j, t} ; I_{D, t} ; L_{R, j, t}} E_{t} \sum_{t=0}^{\infty} \beta^{t} S_{t}^{p}\left\{\frac{\left(C_{R, j, t}-\phi_{C} C_{R, j, t-1}\right)^{1-\sigma}}{1-\sigma}-S_{t}^{L}\left[\frac{L_{R, j, t}^{1+\varphi}}{1+\varphi}\right]\right\}
$$

subject to

$$
\begin{aligned}
& P_{t}\left(1+\tau_{c}\right)\left(C_{R, j, t}+I_{D, t}\right)+\frac{B_{j, t+1}}{R_{t}^{B}}+R_{t-1}^{F} S_{t} B_{j, t}^{F}=W_{t} L_{j, t}\left(1-\tau_{l}-\tau_{p}\right)+R_{t} U_{t} K_{D, j, t}\left(1-\tau_{k}\right) \\
& -P_{t} K_{D, j, t}\left[\Psi_{1}\left(U_{j, t}-1\right)+\frac{\Psi_{2}}{2}\left(U_{j, t}-1\right)^{2}\right]+B_{j, t}+S_{t} B_{j, t+1}^{F}-\frac{\chi_{B F}}{2}\left(B_{j, t+1}^{F}-B_{j, s s}^{F}\right)^{2} S_{t}
\end{aligned}
$$

where $\beta$ is the intertemporal discount factor; $C_{R}$ is the part of aggregate consumption consumed by Ricardian households; $L_{R}$ is labor; $S^{P}$ is the intertemporal consumption shock; $S^{L}$ is a labor supply shock; $\phi$ is the marginal disutility of labor, and $\sigma$ is the relative risk aversion coefficient. Additionally, $I$ is investment; $B$ is the stock of government and foreign bonds maturing in one period; $R^{B}$ is the government bond interest rate; $W$ is the wage rate; $R$ is the rate of return to capital, $K ; S$ is the nominal exchange rate; $U$ is the utilization capacity of capital; and $\tau^{c}, \tau^{l}$, and $\tau^{s}$ are, respectively, the consumption, labor income, and capital income taxes, while $\tau^{s}$ is the rate of social security contribution. The term $\left(\chi_{B F} / 2\right)\left(B_{t+1}^{F}-B_{S S}^{F}\right)^{2} S_{t}$ represents a stationary-inducing technique suggested by Schmitt-Grohé and Uribe (2003).

The law of motion for domestic capital is given by

$$
K_{t+1}=(1-\delta) K_{t}+I_{t}\left[1-\frac{\chi}{2}\left(\frac{I_{t}}{S_{t}^{I} I_{t-1}}-1\right)^{2}\right]
$$

while for households we have shocks to the intertemporal substitution preferences:

$$
\log S_{t}^{P}=\rho^{P} S_{t-1}^{P}+\varepsilon_{P, t}
$$


where $\varepsilon_{P, t} \sim N\left(0, \sigma^{P}\right)$.

Shock to labor supply

where $\varepsilon_{L, t} \sim N\left(0, \sigma^{L}\right)$.

$$
\log S_{t}^{L}=\rho^{L} S_{t-1}^{L}+\varepsilon_{L, t}
$$

Shock in investment productivity:

where $\varepsilon_{I, t} \sim N\left(0, \sigma^{I}\right)$.

$$
\log S_{t}^{I}=\rho^{I} S_{t-1}^{I}+\varepsilon_{I, t}
$$

Solving the Ricardian optimization problem, we get:

$$
\begin{gathered}
\left(1+\tau_{t}^{c}\right) P_{t} \lambda_{R, t}=S_{t}^{P}\left(C_{R, t}-\varphi_{c} C_{R, t-1}\right)^{-\sigma}-\varphi_{c} E_{t} \beta\left[S_{t+1}^{P}\left(C_{R, t+1}-\varphi_{c} C_{R, t}\right)^{-\sigma}\right] \\
Q_{t}=E_{t} \beta\left\{(1-\delta) Q_{t+1}+\lambda_{R, t} R_{t+1} U_{t+1}\left(1-\tau_{t+1}^{k}\right)-\lambda_{R, t+1} P_{t+1}\left[\psi_{1}\left(U_{t+1}-1\right)+\frac{\psi_{2}}{2}\left(U_{t+1}-1\right)^{2}\right]\right\} \\
\frac{R_{t}}{P_{t}}=\left(\frac{1}{\left(1-\tau_{t}^{k}\right)}\right) \\
\lambda_{R, t} P_{t}-Q_{t}\left[1-\frac{\chi}{2}\left(\frac{I_{t}}{S_{t}^{I} I_{t-1}}-1\right)^{2}-\chi\left(\frac{I_{t}}{S_{t}^{I} I_{t-1}}\right)\left(\frac{I_{t}}{S_{t}^{I} I_{t-1}}-1\right)\right]=\chi \beta E_{t}\left[\frac{Q_{t+1}}{S_{t+1}^{I}}\left(\frac{I_{t+1}}{I_{t}}\right)^{2}\left(\frac{I_{t+1}}{S_{t+1}^{I} I_{t}}-1\right)\right] \\
\frac{\lambda_{R, t}}{R_{t}^{B}}=E_{t} \beta \lambda_{R, t+1} \\
E_{t} \beta R_{t}^{F}\left(\lambda_{R, t+1} S_{t+1}\right)=\lambda_{R, t} S_{t}\left[1-\chi_{B F}\left(B_{t+1}^{F}-B_{S S}^{F}\right)\right]
\end{gathered}
$$

\subsection{Wage Setting}

The household choice over the wage level entails the assumption that this agent provides differentiated labor in a monopolistically competitive framework. Labor is sold to a representative labor aggregator that combines all those different labor services $L_{j, t}$ into a single input, $L_{t}$, by means of a Dixit-Stiglitz (1977) technology:

subject to the following constraint:

$$
\max _{L_{j, t}} W_{t} L_{t}-\int_{0}^{1} W_{j, t} L_{j, t} d j
$$

The first order condition results in:

$$
L_{t}=\left[\int_{0}^{1} L_{j, t} \frac{\psi w-1}{\psi w} d j\right]^{\frac{\psi w}{\psi w-1}}
$$

$$
L_{j, t}=L_{t}\left(\frac{w_{t}}{W_{j, t}}\right)^{\psi w}
$$

This equation represents the representative labor aggregator demand. By substituting this result into equation (17), we get the aggregate wage level:

$$
W_{t}=\left[\int_{0}^{1} W_{j, t}^{1-\psi w} d j\right]^{\frac{1}{1-\psi w}}
$$

Each period, a fraction $1-\theta_{W}$ of households, randomly selected, select their wage efficiently. The other fraction of households, $\theta_{W}$, follow a sticky-wage rule $W_{j, t}=W_{j, t-1}$. When making the decision on the wage level for period $t$, the wage-efficient households recognize that they face the probability $\theta_{W}^{N}$ on the wage being fixed for $N$ periods in the future, regardless of whether they select the optimal wage level, $W_{j, t}{ }^{*}$, in the current period. Accordingly, the household needs to solve the following problem:

$$
\max _{W_{j, t}^{*}} E_{t} \sum_{i=0}^{\infty}\left(\beta \theta_{W}\right)^{i}\left[-S_{t+i}^{P} S_{t+i}^{L} \frac{L_{Z, j, t+i}^{1+\phi}}{1+\phi}-\lambda_{Z, j, t+i}\left[-W_{j, t}^{*} L_{Z, j, t+i}\left(1-\tau_{t}^{l}\right)\right]\right]
$$

where $Z=\{R, N R\}$, subject to the demand for labor from the aggregator, given by equation (19).

Solving the problem, we get the following first order conditions:

$$
\begin{aligned}
W_{j, t}^{*} & =\left(\frac{\psi_{W}}{\psi_{W}-1}\right) E_{t} \sum_{i=0}^{\infty}\left(\beta \theta_{W}\right)^{i}\left[\frac{S_{t+i}^{C} S_{t+i}^{L} L_{R, j, t+i}^{\varphi}}{\lambda_{R, j, t+i}\left(1-\tau_{l}\right)}\right] \\
W_{j, t}^{*} & =\left(\frac{\psi_{W}}{\psi_{W}-1}\right) E_{t} \sum_{i=0}^{\infty}\left(\beta \theta_{W}\right)^{i}\left[\frac{S_{t+i}^{C} S_{t+i}^{L} L_{N R, j, t+i}^{\varphi}}{\lambda_{N R, j, t+i}\left(1-\tau_{l}\right)}\right]
\end{aligned}
$$

Given that a fraction $1-\theta_{W}$ of households, randomly selected, sets the same optimal wage level, $W_{j, t}^{*}=W_{t}^{*}$, 
and the other fraction receives the same wage as in the previous period, the aggregate nominal wage level can be written as:

$$
W_{t}^{*}=\left[\theta_{W} W_{t-1}^{1-\psi_{W}}+\left(1-\theta_{W}\right) W_{t}^{* 1-\psi_{W}}\right]^{\frac{1}{1-\psi_{W}}}
$$

The gross wage inflation rate is then given by,

$$
\pi_{W_{t}}=\frac{W_{t}}{W_{t-1}}
$$

Aggregate labor can be obtained as follows:

$$
L_{t}=\omega_{R} L_{R, t}+\left(1-\omega_{R}\right) L_{N R, t}
$$

\subsection{Firms and Production}

\subsubsection{Final Goods Production}

Suppose that production takes place in two different regions of the country: region 1 (Bogota, the center) and region 2 (the periphery, the rest of the country - ROC) and each region has two types of firms (final goods and intermediate goods). Let's assume, first, that each intermediate firm sells its output to either final good firms or exports it to the rest of the world, and, second, that each final good firm (a retailer) purchases a large variety of wholesale goods from intermediate firms, puts them into a bundle (a package comprised of all goods), and sells this aggregate good (the bundle) to the country in a perfectly competitive market or exports it to the rest of the world. This means that all final good firms (the retailers) are all identical to one another; likewise, for intermediate good firms.

In order to present the problem that faces a retailer and solve it, we must, first, describe its production technology and, second, obtain the price at which it sells its output. Total output is obtained by the Dixit-Stiglitz (1977) aggregator.

$$
Y_{t}=\left(\int_{0}^{1} Y_{j, t}^{(\psi-1) / \psi} d j\right)^{\psi /(\psi-1)} \quad i=1,2
$$

where $j \in[0,1]$ and $\psi>1$ is the elasticity of substitution among wholesale goods. It is worth mentioning that the price of each wholesale good is taken as given by the retailer. Now, let $P_{t}$ and $P_{j, t}$ be the price of the retailer good and the price of the wholesale good, $j$, respectively. Then, the representative firm maximization problem can be written as

$$
\max _{Y_{j, t}} P_{t} Y_{t}-\int_{0}^{1} P_{j, t} Y_{j, t} d j
$$

The first order condition leads us to:

$$
Y_{j, t}=Y_{t}\left(\frac{P_{t}}{P_{j, t}}\right)^{\psi}
$$

This is the demand function for the wholesale good, $j$, that increases with aggregate demand, $Y_{t}$, and is inversely related to its relative price level.

Next, the substitution of equation (29) into equation (27) yields the aggregate price level:

$$
P_{t}=\left[\int_{0}^{1} P_{j, t}^{1-\psi} d j\right]^{1 /(1-\psi)}
$$

\subsubsection{Intermediate (Wholesale) Goods Production}

In order to determine the optimal price that intermediate firms will use to sell their products, it is necessary to split the problem into three related different problems. First, intermediate firms in each region $(Z=\{B o g, R O C\})$ take input prices, salaries $(W)$ and the cost of use of capital $(R)$, as given and find the domestic factor demand functions under the assumption of cost minimization. Second, to determine their output rate these firms must choose between domestic and imported inputs. And third, under the assumption of profit maximization, they must determine the optimal price to sell their product.

The cost minimization problem. For a representative intermediate good firm, this first problem can be stated as follows:

$$
\min W_{t} L_{Z, j, t}+R_{t} K_{Z, j, t}
$$

subject to the production function of inputs given by:

$$
I N P_{Z, i, j}^{D}=A_{Z, t}\left(\left(U_{Z, t} K_{Z, j, t}\right)^{\alpha_{K, Z}} F D I_{Z, j, t}^{\alpha_{F, Z}} L_{Z, j, t}^{\alpha_{L, Z}}\right.
$$

Where $F D I_{Z, j, t}^{\alpha_{F, Z}}$ is foreign direct investment, and $L_{Z, j, t}$ and $K_{Z, j, t}$ are labor and capital, respectively. 
$A_{Z, t}$ is a multifactor productivity index that follows the law of motion:

$$
\log A_{Z, t}=\rho_{A, Z} A_{Z, t-1}+\epsilon_{A, Z, t}
$$

where $\epsilon_{A, Z, t} \sim N\left(0, \sigma^{A, Z}\right)$.

The FDI shock to in any region $\mathrm{Z}$ of the country follows

$$
\log F D I_{Z, i, t}=\rho_{F D I, Z} F D I_{Z, t-1}^{F}+\epsilon_{F D I, Z, t}
$$

where $\epsilon_{F D I, Z, t} \sim N\left(0, \sigma^{F D I, Z}\right)$

The first order conditions are given by:

$$
\begin{gathered}
L_{Z, j, t}=\frac{\alpha_{L, Z} I N P_{Z, j, t}^{D}}{\frac{W_{t}}{P_{Z, t}^{D}}} \\
U_{Z, t} K_{Z, j, t}=\frac{\alpha_{K, Z} I N P_{Z, j, t}^{D}}{\frac{R_{t}}{P_{Z, t}^{D}}}
\end{gathered}
$$

The marginal cost can be determined by substituting equations (35) and (36) into equation (32) to obtain:

$$
P_{t}^{D}=\left(\frac{1}{A_{t} F D I_{Z, j, t}^{\alpha_{F}, Z}}\right)\left(\frac{R_{t}}{\alpha_{K, Z}}\right)^{\alpha_{K, Z}}\left(\frac{w_{t}}{\alpha_{L, Z}}\right)^{\alpha_{L, Z}}
$$

Production of Aggregate Domestic Inputs. In the second step, firms must decide between domestic and imported inputs. The techonology used by these firs is given by:

$$
Y_{Z, j, t}=\left[\omega_{D, Z} \frac{1}{\varphi_{D, Z}}\left(I N P_{Z, j, t}^{D D}\right)^{\frac{\varphi_{D, Z}-1}{\varphi_{D, Z}}}+\left(1-\omega_{D, Z}\right)^{\frac{1}{\varphi_{D, Z}}}\left(I N P_{Z, j, t}^{F D}\right)^{\frac{\varphi_{D, Z}-1}{\varphi_{D, Z}}}\right]^{\frac{\varphi_{D}}{\varphi_{D}-1}}
$$

Where $\omega_{D}$ is the share of domestic inputs in the production of the intermediate goods, and $\varphi_{D}$ is the elasticity of substitution between domestic and imported inputs. This problem can be written in the following way:

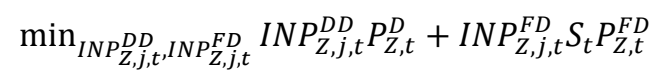

subject to equation (38). From the first orders conditions, we obtain:

$$
\begin{gathered}
I N P_{Z, j, t}^{D D}=\omega_{D, Z}\left(\frac{M C_{Z, j, t}}{P_{Z, t}^{D}}\right)^{\varphi_{D, Z}} Y_{Z, j, t} \\
I N P_{Z, j, t}^{F D}=\left(1-\omega_{D, Z}\right)\left(\frac{M C_{Z, j, t}}{S_{t} P_{t}^{F}}\right)^{\varphi_{D, Z}} Y_{Z, j, t}
\end{gathered}
$$

with

$$
I N P_{Z, j, t}^{D}=I N P_{Z, j, t}^{D D}+I N P_{Z, j, t}^{F D}
$$

where $I N P_{Z, j, t}^{D D}$ is the input produced and used by Colombia, $I N P_{Z, j, t}^{F D}$ is the input produced in Colombia and used by the rest of the world. As a result, marginal cost results in:

$$
M C_{Z, j, t}=\left[\varphi_{D, Z}\left(P_{Z, t}^{D}\right)^{1-\varphi_{D, Z}}+\left(1-\varphi_{D, Z}\right)\left(S_{t} P_{t}^{F}\right)^{1-\varphi_{D, Z}}\right]^{\frac{1}{1-\varphi_{D, Z}}}
$$

Price rigidity. The third step consists in determining the optimal price for the final good. Suppose that intermediate good firms set the price for their product following the staggered price system suggested by Calvo (1983). This system suggests that there is a probability $0<\theta_{Z}<1$ that firms not always select their optimal price. More precisely, these firms keep their price fixed in the next period, $P_{z, j, t}=P_{z, j, t-1}$. By the same token, there is a probability $1-\theta_{Z}$ that firms will select their price optimally, $P_{Z, j, t}^{*}$. Once a firm sets its price in period $t$, there is a probability $\theta_{Z}$ that the firm will keep the same price in period $t+1$. Moreover, there is also a probability $\theta_{Z}{ }^{2}$ that the firm will continue charging the same price in $t+2, \theta_{z}{ }^{3}$ in $t+3$, and so on. A firm able to choose its optimal price must take these probabilities into account. Consequently, and in order to select its optimal price, this firm must solve the following optimization problem.

$$
\max _{P_{i, j, t}^{*}} E_{t} \sum_{i=0}^{\infty}\left(\beta \theta_{Z}\right)^{i} Y_{Z, j, t+1}\left[P_{Z, j, t}^{*}-M C_{Z, j, t+i}\right]
$$

Subject to equation (29).

The solution to this problem is given by equation (45)

$$
P_{Z, j, t}^{*}=\left(\frac{\psi_{Z}}{1-\psi_{Z}}\right) E_{t}\left(\beta \theta_{Z}\right)^{i} M C_{Z, j, t+i}
$$

It is worth noting that all wholesale firms setting their prices share the same markup over the same marginal cost. 
This implies that in all periods $P_{Z, j, t}^{*}$ is the same for all $1-\theta_{Z}$ firms adjusting their price. According to these pricing rules and equation (30), the overall price level is given by:

\subsection{The Public Sector}

$$
P_{Z, t}=\left[\theta_{Z}\left(P_{Z, t-1}\right)^{1-\psi_{Z}}+\left(1-\theta_{Z}\right)\left(P_{Z, t}^{*}\right)^{1-\psi_{Z}}\right]^{\frac{1}{1-\psi_{Z}}}
$$

In this economy, the public sector performs its activity by means of two separate independent authorities: the fiscal authority and the monetary authority.

\subsubsection{Fiscal Authority}

The government as fiscal authority collects taxes from households and firms, and issue bonds to finance its outlays such as current spending, $G_{t}$, and pensions to retired agents, $P E N_{t}$. Therefore, the government's budget constraint can be written as follows:

$$
\frac{B_{t+1}}{R_{t}^{B}}-B_{t}+T_{t}=P_{t} G_{t}+P_{t} P E N_{t}-\tau_{t}^{p} W_{t} L_{t}
$$

where the overall tax collection, $T_{t}$, is given by:

$$
T_{t}=\tau_{t}^{C} C_{t} P_{t}+\tau_{t}^{L} W_{t} L_{t}+\tau_{t}^{K}\left(R_{t}-\delta\right) K_{t}
$$

and $\delta$ is the rate of depreciation of domestic capital.

The government has at its disposal 2 expenditure based fiscal policy tools: $G_{t}$ and $P E N_{t}$, and four revenue based tools: $\tau_{t}^{C}, \tau_{t}^{L}, \tau_{t}^{L}$, and $\tau_{t}^{p}$. All these instruments follow the same policy rule:

$$
\frac{\Lambda_{t}}{\Lambda_{s s}}=\left(\frac{\Lambda_{t-1}}{\Lambda_{s s}}\right)^{\gamma_{\Lambda}}\left(\frac{B_{t}}{Y_{t-1} P_{t-1}} \frac{Y_{S S} P_{S S}}{B_{S S}}\right)^{\left(1-\gamma_{\Lambda}\right) \phi_{\Lambda}} S_{t}^{\Lambda}
$$

where $\gamma_{\Lambda}$ and $\phi_{\Lambda}$ are parameters capturing the importance of these fiscal policy tools relative to public debt sustainability and the importance of the debt level relative to GDP, respectively, and $\Lambda=\left\{G_{t}, P E N_{t}, \tau_{t}^{C}, \tau_{t}^{L}\right.$, $\left.\tau_{t}^{L}, \tau_{t}^{p}\right\} . S_{t}^{\Lambda}$ is a fiscal shock that impacts the economy according to:

$$
\log S_{t}^{\Lambda}=\rho_{\Lambda} S_{t}^{\Lambda}+\epsilon_{\Lambda, t}
$$

where $\epsilon_{\Lambda, t} \sim N\left(0, \sigma^{\Lambda}\right)$.

\subsubsection{The Central Bank and Monetary Authority}

Let's assume that the central bank follows a simple Taylor rule with a dual goal: output growth and price stability.

$$
\frac{R_{t}^{B}}{R_{S S}^{B}}=\left(\frac{R_{t-1}^{B}}{R_{S S}^{B}}\right)^{\gamma_{R}}\left[\left(\frac{\pi_{t}}{\pi_{S S}}\right)^{\gamma_{\pi}}\left(\frac{Y_{t}}{Y_{S S}}\right)^{\gamma_{Y}}\right]^{\left(1-\gamma_{R}\right)} S_{t}^{m}
$$

where $\gamma_{\pi}$ and $\gamma_{Y}$ are sensitivity coefficients of the bonds interest rate to price stability and output growth, $\gamma_{R}$ is the stabilization parameter, and $S_{t}^{m}$ is a monetary shock, which behaves by the rule shown in the next equation

where $\epsilon_{m, t} \sim N\left(0, \sigma^{m}\right)$.

$$
\log S_{t}^{m}=\rho_{m} S_{t-1}^{m}+\epsilon_{m, t}
$$

\subsection{The Foreign Sector}

It is assumed that exports of the domestic economy are homogeneous goods before leaving the docks but are well differentiated in the world market. Goods exported to the rest of the world are: consumer goods and inputs used in the production process of the rest of the world.

\subsubsection{Rest of the World Hourseholds}

There is a continuum of families in the rest of the world indexed by $j$ in $[0,1]$. This representative family maximizes its intertemporal utility by choosing consumption:

$$
\max _{X_{j, t} ; C_{j, t}^{F F}} E_{t} \sum_{t=0}^{\infty} \beta^{t}\left(\frac{X_{j, t}^{1-\sigma}}{1-\sigma}\right)
$$

With the following aggregation technology:

$$
C_{j, t}^{F}=\left[\left(1-\vartheta_{C}^{F}\right)^{1 / v_{C}^{F}}\left(C_{j, t}^{F F}\right)^{\left(v_{C}^{F}-1\right) / v_{C}^{F}}+\left(\vartheta_{C}^{F}\right)^{1 / v_{C}^{F}}\left(X_{j, t}\right)^{\left(v_{C}^{F}-1\right) / v_{C}^{F}}\right]^{v_{C}^{F} /\left(v_{C}^{F}-1\right)}
$$

Subject to the following budget constraint, 


$$
X_{j, t} P_{t}^{D, C}+C_{F, j, t}^{F} S_{t} P_{t}^{F}=Y_{t}^{F} S_{t} P_{t}^{F}
$$

The result of the previous problem is,

$$
\begin{gathered}
X_{j, t}=\left(\frac{\vartheta_{C}^{F}}{1-\vartheta_{C}^{F}}\right)\left(\frac{s_{t} P_{t}^{F}}{P_{t}^{D ; C}}\right)^{\nu_{C}^{F}} C_{F, j, t}^{F} \\
C_{F, j, t}^{F}=\phi_{C_{F}^{F}} Y_{t}^{F}
\end{gathered}
$$

where $X_{j, t}$ are exports from Colombia to the rest of the world with a price $P_{t}^{D ; C}, C_{F, j, t}^{F}$ is the consumer good produced in the rest of the world with a price $P_{t}^{F}, \vartheta_{C}^{F}$ is the share of this exported good in the rest of the world's consumption basket, $v_{C}^{F}$ is the elasticity of substitution between the consumer goods of Colombia and the rest of the world, and $\phi_{C_{F}^{F}}$ is the share of household consumption $\left(C_{F, j, t}^{F}\right)$ in the $\operatorname{GDP}\left(Y_{t}^{F}\right)$ of the rest of the world.

\subsubsection{Production of Intermediate Foreign Goods}

In the production process of the rest of the world, imported inputs of the domestic economy and produced internally are used:

$$
\min _{I N P_{Z, j, t}^{D F} I N P_{Z, j, t}^{F F}} I N P_{Z, j, t}^{D, F} P_{Z, t}^{D, Z}+I N P_{Z, j, t}^{F, F} S_{t} P_{Z, t}^{F}
$$

subject to

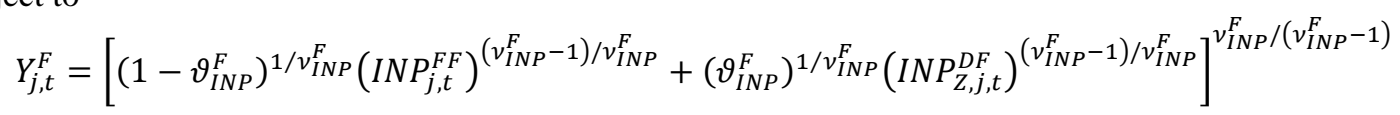

where $I N P_{j, t}^{F F}$ is the input produced and used by the rest of the world, $\vartheta_{I N P}^{F}$ is the share of the input produced by Colombia in the production of the rest of the world, and $v_{I N P}^{F}$ is the elasticity of substitution of the inputs produced by Colombia and the rest of the world in the production of the rest of the world.

The first order conditions for the previous problem,

$$
I N P_{Z, j, t}^{D F}=\vartheta_{I N P}^{F}\left(\frac{S_{t} P_{t}^{F}}{P_{t}^{D I I N P}}\right)^{v_{I N P}^{F}} Y_{j, t}^{F}
$$

The equation that shows the equilibrium condition for the balance of payments is next:

$$
\begin{gathered}
S_{t}\left[\left(B_{t+1}^{F}-R_{t-1}^{F} B_{t}^{F}\right)+\left(F D I_{B O G, t}+F D I_{R O C, t}-D O V_{B O G, t}^{F}-D I V_{R O C, t}^{F}\right)\right]= \\
S_{t} P_{t}^{F}\left(I N P_{B O G, t}^{F D}+I N P_{T O C, t}^{F}\right)-P_{B O G, t}\left(X_{B O G, t}+I N P_{B O G, t}^{D F}\right)-P_{R O C, t}\left(X_{R O C, t}+I N P_{R O C, t}^{D F}\right)
\end{gathered}
$$

where dividends represent a share of firms' profits,

$$
D I V_{Z, t}^{F}=d P R O F I T_{t}
$$

The laws of motion for the foreign interest rates, the import price level and foreign GDP are shown in equations (56) to (57):

where $\epsilon_{R_{F}, t} \sim N\left(0, \sigma^{R_{F}}\right)$.

$$
\log R_{t}^{F}=\rho_{R_{F}} R_{t-1}^{F}+\epsilon_{R_{F}, t}
$$

$$
\log P_{t}^{F}=\rho_{P_{F}} P_{t-1}^{F}+\epsilon_{P_{F}, t}
$$

where $\epsilon_{P_{F}, t} \sim N\left(0, \sigma^{P_{F}}\right)$.

$$
\log Y_{t}^{F}=\rho_{Y_{F}} Y_{t-1}^{F}+\epsilon_{Y_{F}, t}
$$

where $\epsilon_{Y_{F}, t} \sim N\left(0, \sigma^{Y_{F}}\right)$.

\subsection{Closing the Model}

To close the model, we use the good market equilibrium condition given by:

\section{Analysis of Results}

$$
Y_{t}=C_{t}+I_{t}+G_{t}+X_{t}
$$

\subsection{Data}

We then proceed to estimate the model using annual data spanning from 2002 to 2015 . We use 14 model variables as observable which they are described in table 1 . So, to prepare the data for the model estimation, we detrented non-stationary series using the first log-difference. We have chosen this set of observables due to data availability and their relevance to our research purposes. Furthermore, a large set of observables increases the problem of identification. 
Table 1. Observable variables of the model

\begin{tabular}{|c|c|}
\hline Series & Source \\
\hline $\begin{array}{c}\text { Real consumption Colombia } \\
\text { (Billions National Currency Constant Prices of 2005) }\end{array}$ & DANE: Estadísticas por tema: Cuentas Nacionales \\
\hline $\begin{array}{l}\text { Gross Fixed Capital Formation Colombia } \\
\text { (Billions National Currency Constant Prices of 2005) }\end{array}$ & DANE: Estadísticas por tema: Cuentas Nacionales \\
\hline $\begin{array}{c}\text { Real GDP Colombia } \\
\text { (Billions National Currency Constant Prices of 2005) }\end{array}$ & DANE: Estadísticas por tema: Cuentas Nacionales \\
\hline $\begin{array}{c}\text { Real Exports Colombia } \\
\text { (Billions National Currency Constant Prices of 2005) }\end{array}$ & DANE: Estadísticas por tema: Cuentas Nacionales \\
\hline $\begin{array}{c}\text { Real Imports } \\
\text { (Billions National Currency Constant Prices of 2005) }\end{array}$ & DANE: Estadísticas por tema: Cuentas Nacionales \\
\hline $\begin{array}{c}\text { Foreign Direct Investment Colombia } \\
\text { (Millions of US dollars) }\end{array}$ & DANE: Estadísticas por tema: Cuentas Nacionales \\
\hline $\begin{array}{l}\text { Real Exports Bogota } \\
\text { (Billions National Currency Constant Prices of 2005) }\end{array}$ & DANE: Estadísticas por tema: Cuentas Nacionales \\
\hline $\begin{array}{l}\text { FDI Bogota Green Field Expansion } \\
\text { (Millions of US dollars) }\end{array}$ & DANE: Estadísticas por tema: Cuentas Nacionales \\
\hline $\begin{array}{c}\text { Real GDP Bogota } \\
\text { (Billions National Currency Constant Prices of 2005) }\end{array}$ & DANE: Estadísticas por tema: Cuentas Nacionales \\
\hline Average hours of labor per week Colombia & DANE: Microdatos \\
\hline Average hours of labor per week Bogota & DANE: Microdatos \\
\hline Inflation Rate Colombia (percentage) & DANE: Estadísticas por tema: Cuentas Nacionales \\
\hline $\begin{array}{l}\text { Average exchange rate } \\
\text { (Pesos per US dollar) }\end{array}$ & DANE: Estadísticas por tema: Cuentas Nacionales \\
\hline $\begin{array}{l}\text { Social Security Payments Colombia } \\
\text { (Percentage out of GDP) }\end{array}$ & DANE \\
\hline $\begin{array}{l}\text { Government Revenue } \\
\text { (Percentage out of GDP) }\end{array}$ & DANE: Estadísticas por tema: Cuentas Nacionales \\
\hline $\begin{array}{l}\text { Government Expenditures } \\
\text { (Percentage out of GDP) }\end{array}$ & DANE: Estadísticas por tema: Cuentas Nacionales \\
\hline $\begin{array}{c}\text { Internal Debt } \\
\text { (Percentage out of GDP) }\end{array}$ & DANE \\
\hline Gross Domestic Product & IMF - World Economic Outlook Database \\
\hline
\end{tabular}

\subsection{Calibrated Parameters, Prior and Posterior}

In this section we pursue a two-tier approach: the parameters not directly related to the questions we endeavor to answer throughout this article are calibrated, while those relevant parameters for the analysis of the shock propagation are estimated using the Bayesian methodology. The main calibration procedure employed here is to pick up the values of parameters from other relevant articles in the DSGE model literature. Table 2 summarizes the calibration of the parameters.

Table 2. Parameter values for calibration

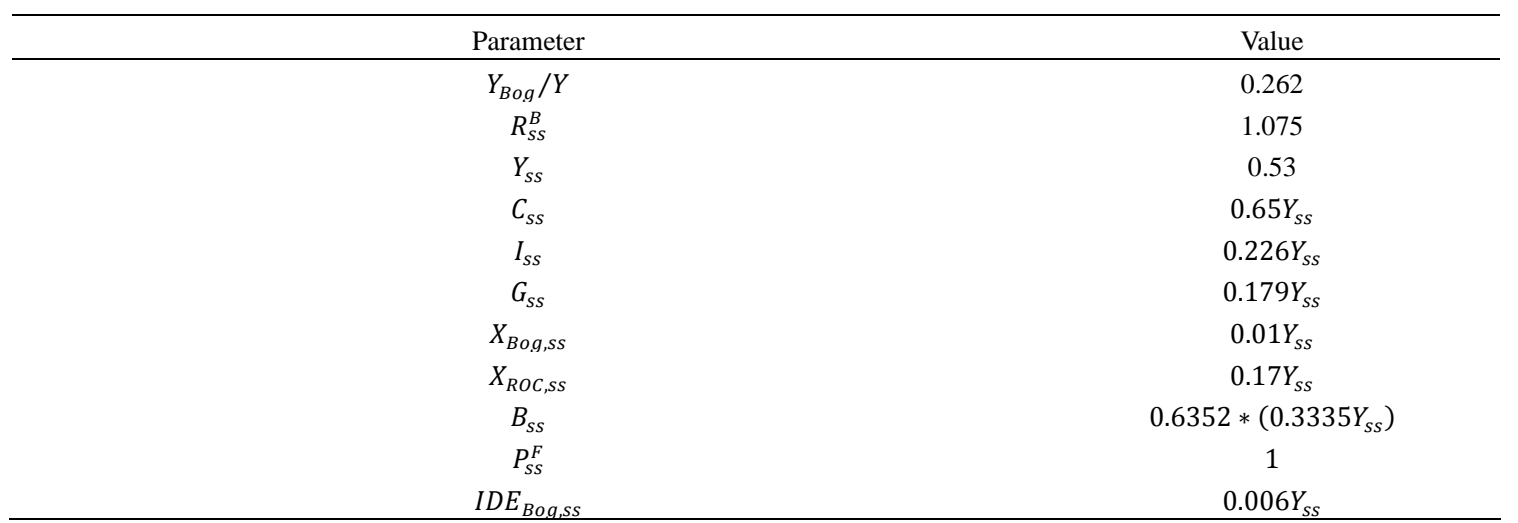




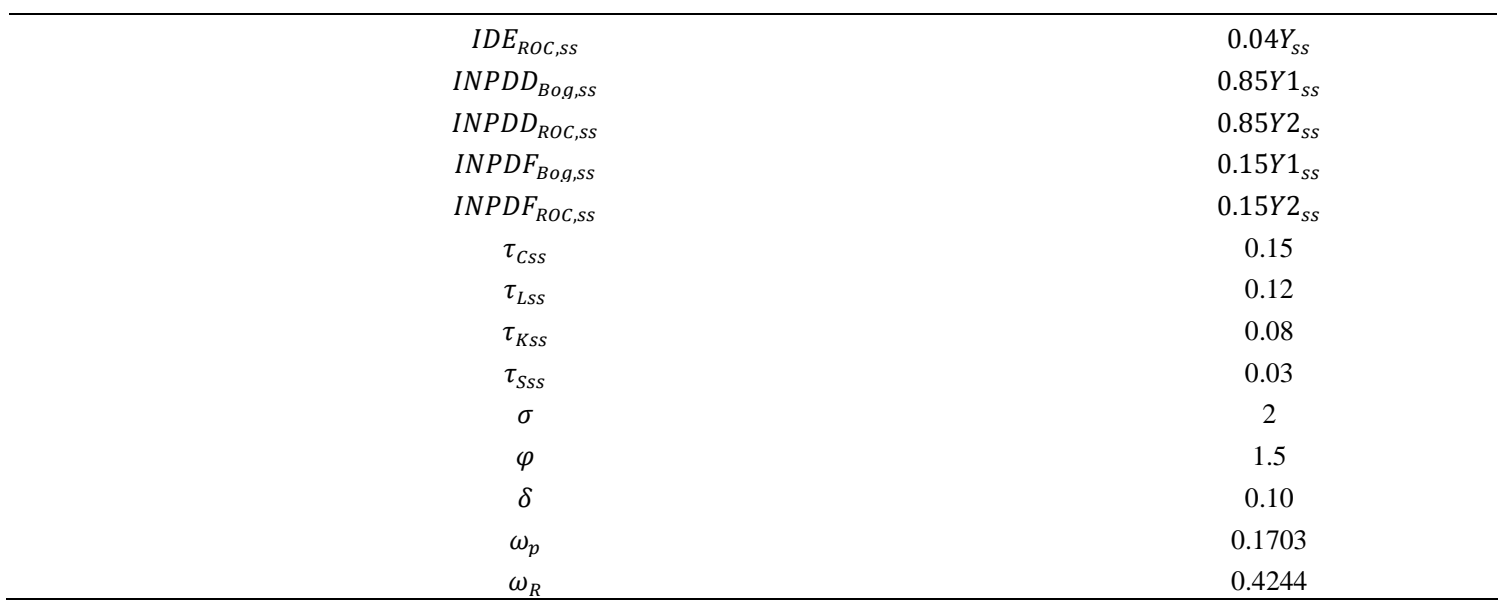

Source: Own calculations.

Given the prior distributions of the parameters, we estimate the posterior distributions using a Markov chain process via the Metropolis-Hastings algorithm with 1.000 .000 iterations, a scale value 0.3 for the jumping distribution, and 2 parallel chains for Metropolis-Hastings algorithm (Note 1). Results of the Bayesian estimation are shown in table 3 and figure 1.

Table 3. Bayesian estimation

\begin{tabular}{|c|c|c|c|c|c|c|}
\hline \multirow{3}{*}{ Parameters } & \multicolumn{6}{|c|}{$90 \%$} \\
\hline & Prior Mean & Post. Mean & \multicolumn{2}{|c|}{ HPD Interval } & prior & pstdev \\
\hline & \multicolumn{5}{|c|}{ General Parameters } & \\
\hline$P_{S S}^{D}$ & 1.050 & 0.1527 & 0.1000 & 0.2172 & unif & 0.5485 \\
\hline$P_{S S}^{D}$ & 7.500 & 57.531 & 50.000 & 66.674 & unif & 14.434 \\
\hline 1 & 1.450 & 13.768 & 12.000 & 15.919 & unif & 0.1443 \\
\hline$p s i^{D}$ & 1.700 & 17.580 & 15.824 & 19.999 & unif & 0.1732 \\
\hline$\theta_{\text {Bog }}$ & 0.080 & 0.0880 & 0.0724 & 0.1000 & unif & 0.0115 \\
\hline$\theta_{R O C}$ & 0.105 & 0.1701 & 0.1314 & 0.2000 & unif & 0.0548 \\
\hline$\omega_{D, B o g}$ & 0.850 & 0.8420 & 0.8000 & 0.8806 & unif & 0.0289 \\
\hline$\omega_{D, R O C}$ & 0.900 & 0.9266 & 0.8981 & 0.9500 & unif & 0.0289 \\
\hline$\alpha_{I D E, B o g}$ & 0.051 & 0.0638 & 0.0257 & 0.1000 & unif & 0.0286 \\
\hline$\alpha_{K, B o g}$ & 0.420 & 0.4077 & 0.4000 & 0.4183 & unif & 0.0115 \\
\hline$\alpha_{I D E, R O C}$ & 0.051 & 0.0616 & 0.0231 & 0.0996 & unif & 0.0286 \\
\hline$\alpha_{K, R O C}$ & 0.360 & 0.3619 & 0.3533 & 0.3700 & unif & 0.0058 \\
\hline$\psi_{F, B o g}$ & 1.500 & 15.389 & 11.101 & 19.989 & unif & 0.2887 \\
\hline$\psi_{F, R O C}$ & 1.500 & 15.040 & 10.828 & 19.400 & unif & 0.2887 \\
\hline$\theta_{W}$ & 0.105 & 0.1423 & 0.0617 & 0.2000 & unif & 0.0548 \\
\hline$\gamma_{R}$ & 0.750 & 0.6491 & 0.6000 & 0.6925 & unif & 0.0866 \\
\hline$\gamma_{\pi}$ & 3.000 & 34.779 & 28.921 & 40.000 & unif & 0.5774 \\
\hline$\gamma_{Y}$ & 0.125 & 0.1399 & 0.0773 & 0.2000 & unif & 0.0433 \\
\hline$\chi$ & 4.500 & 48.689 & 26.316 & 74.255 & unif & 20.207 \\
\hline \multirow[t]{2}{*}{$\psi$} & 5.500 & 49.597 & 40.000 & 60.818 & unif & 0.8660 \\
\hline & \multicolumn{5}{|c|}{ Autoregressive parameters } & \\
\hline$\rho_{A 1}$ & 0.5 & 0.4291 & 0.2991 & 0.5626 & beta & 0.1 \\
\hline$\rho_{A 2}$ & 0.5 & 0.5095 & 0.3606 & 0.6591 & beta & 0.1 \\
\hline$\rho_{I}$ & 0.5 & 0.4741 & 0.3344 & 0.6280 & beta & 0.1 \\
\hline$\rho_{G}$ & 0.5 & 0.4215 & 0.2645 & 0.5783 & beta & 0.1 \\
\hline$\rho_{P E N}$ & 0.5 & 0.5664 & 0.4010 & 0.7388 & beta & 0.1 \\
\hline$\rho_{\tau_{C}}$ & 0.5 & 0.4661 & 0.2921 & 0.6439 & beta & 0.1 \\
\hline$\rho_{\tau_{I_{I}}}$ & 0.5 & 0.4939 & 0.3387 & 0.6619 & beta & 0.1 \\
\hline$\rho_{\tau_{S}}$ & 0.5 & 0.5710 & 0.4431 & 0.6976 & beta & 0.1 \\
\hline$\rho_{\tau_{K}}$ & 0.5 & 0.4523 & 0.3142 & 0.5904 & beta & 0.1 \\
\hline$\rho_{m}$ & 0.5 & 0.2174 & 0.1617 & 0.2776 & beta & 0.1 \\
\hline$\rho_{R F}$ & 0.5 & 0.5541 & 0.4029 & 0.6794 & beta & 0.1 \\
\hline
\end{tabular}




\begin{tabular}{|c|c|c|c|c|c|c|}
\hline$\rho_{P F}$ & 0.5 & 0.5454 & 0.4042 & 0.6887 & beta & 0.1 \\
\hline$\rho_{Y F}$ & 0.5 & 0.5396 & 0.3592 & 0.7178 & beta & 0.1 \\
\hline$\rho_{F D I 1}$ & 0.5 & 0.5184 & 0.3652 & 0.6776 & beta & 0.1 \\
\hline \multirow[t]{2}{*}{$\rho_{F D I 2}$} & 0.5 & 0.6130 & 0.4594 & 0.7670 & beta & 0.1 \\
\hline & \multicolumn{5}{|c|}{ Exogenous shocks } & \\
\hline$\epsilon_{A 1}$ & 1.0 & 0.2771 & 0.1838 & 0.3689 & invg & Inf \\
\hline$\epsilon_{A 2}$ & 1.0 & 0.2728 & 0.1831 & 0.3583 & invg & Inf \\
\hline$\epsilon_{I}$ & 1.0 & 0.3623 & 0.2047 & 0.5214 & invg & Inf \\
\hline$\epsilon_{G}$ & 1.0 & 10.495 & 0.5704 & 14.997 & invg & Inf \\
\hline$\epsilon_{P E N}$ & 1.0 & 0.2339 & 0.1564 & 0.3057 & invg & Inf \\
\hline$\epsilon_{\tau_{C}}$ & 1.0 & 0.5191 & 0.2398 & 0.7975 & invg & Inf \\
\hline$\epsilon_{\tau_{L}}$ & 1.0 & 0.2669 & 0.1718 & 0.3546 & invg & Inf \\
\hline$\epsilon_{\tau_{S}}$ & 1.0 & 0.6375 & 0.2344 & 10.633 & invg & Inf \\
\hline$\epsilon_{\tau_{K}}$ & 1.0 & 0.4768 & 0.2277 & 0.7251 & invg & Inf \\
\hline$\epsilon_{m}$ & 1.0 & 0.4371 & 0.2598 & 0.6041 & invg & Inf \\
\hline$\epsilon_{R F}$ & 1.0 & 0.3440 & 0.1965 & 0.4849 & invg & Inf \\
\hline$\epsilon_{P F}$ & 1.0 & 0.2619 & 0.1749 & 0.3467 & invg & Inf \\
\hline$\epsilon_{Y F}$ & 1.0 & 0.2511 & 0.1733 & 0.3277 & invg & Inf \\
\hline$\epsilon_{F D I 1}$ & 1.0 & 0.3874 & 0.2326 & 0.5457 & invg & Inf \\
\hline$\epsilon_{F D I 2}$ & 1.0 & 0.3519 & 0.2148 & 0.4843 & invg & Inf \\
\hline$\epsilon_{A}$ & 1.0 & 0.2787 & 0.1834 & 0.3723 & invg & Inf \\
\hline$\epsilon_{I D E}$ & 1.0 & 0.4299 & 0.2614 & 0.5996 & invg & Inf \\
\hline
\end{tabular}

Source: Own calculations.

These graphs are especially relevant in that they present key results, but they can also serve as tools to detect problems or build additional confidence on oneself results. First, the prior and the posterior distribution should not be excessively different from one another. Second, the posterior distributions should be close to normal, or at least not display a shape that is clearly non-normal. And, third, the green mode should not be too far away from the mode of the posterior distribution. Overall, it is worth pointing out that the estimates proved to be quite satisfactory.

\subsection{Results}

Here, we present the results of an increase in foreign direct investment (FDI) from three different experiments: i) the increase in FDI spreads evenly on the Colombian economy (Black line); ii) the increase of FDI that only affects the region of Bogota (red line); and iii) the increase of FDI that affects only the rest of the country (ROC, blue line). In order to carry out the analysis, we assumed a $10 \%$ increase in FDI for the impulse-response functions (IRFs) and shocks decomposition.

\subsubsection{FDI in Colombia}

According to the IRFs shown in figures 2, 3, and 4, a 10\% increase in FDI throughout Colombia causes an increase on the capital stocks of Bogota and the ROC but reduces employment at both regions with a higher effect in Bogota.These effects of course reduce real output, which eventually induces a fall in investment. Inflation falls and, as a result, real balances increase and the Banco de la Republica reacts reducing the money supply to keep the domestic real interest constant. Government spending falls and reduces public debt. After two years, the government reduces consumption, income, and capital taxes and social security contributions in order to recover consumption and investment. As consumption and investment recovers, capital and employment markets adjust and return to their steady state levels and so do government spending, inflation, public debt, and real output.

\subsubsection{FDI in Bogota}

Suppose there is a 10\% increase in FDI in the region of Bogota. The IRFs are shown by red lines in figures 2, 3, and 4. Right after the shock, real output goes down as a result of the contraction of the stocks of capital in both regions but the effect on Bogota is larger. Employment rises in Bogota which pushes wages up reducing employment in ROC. Consumption and government spending fall induced by the real output contraction reducing the price level as well and causing an appreciation of the domestic currency. The domestic real interest rate rises causing a fall in investment. However, the Banco de la Republica reacts by increasing domestic credit and lowering the domestic interest rate stimulating investment, increasing inflation, and rising real output. Final results indicate that macroeconomic variables return to steady state values. 

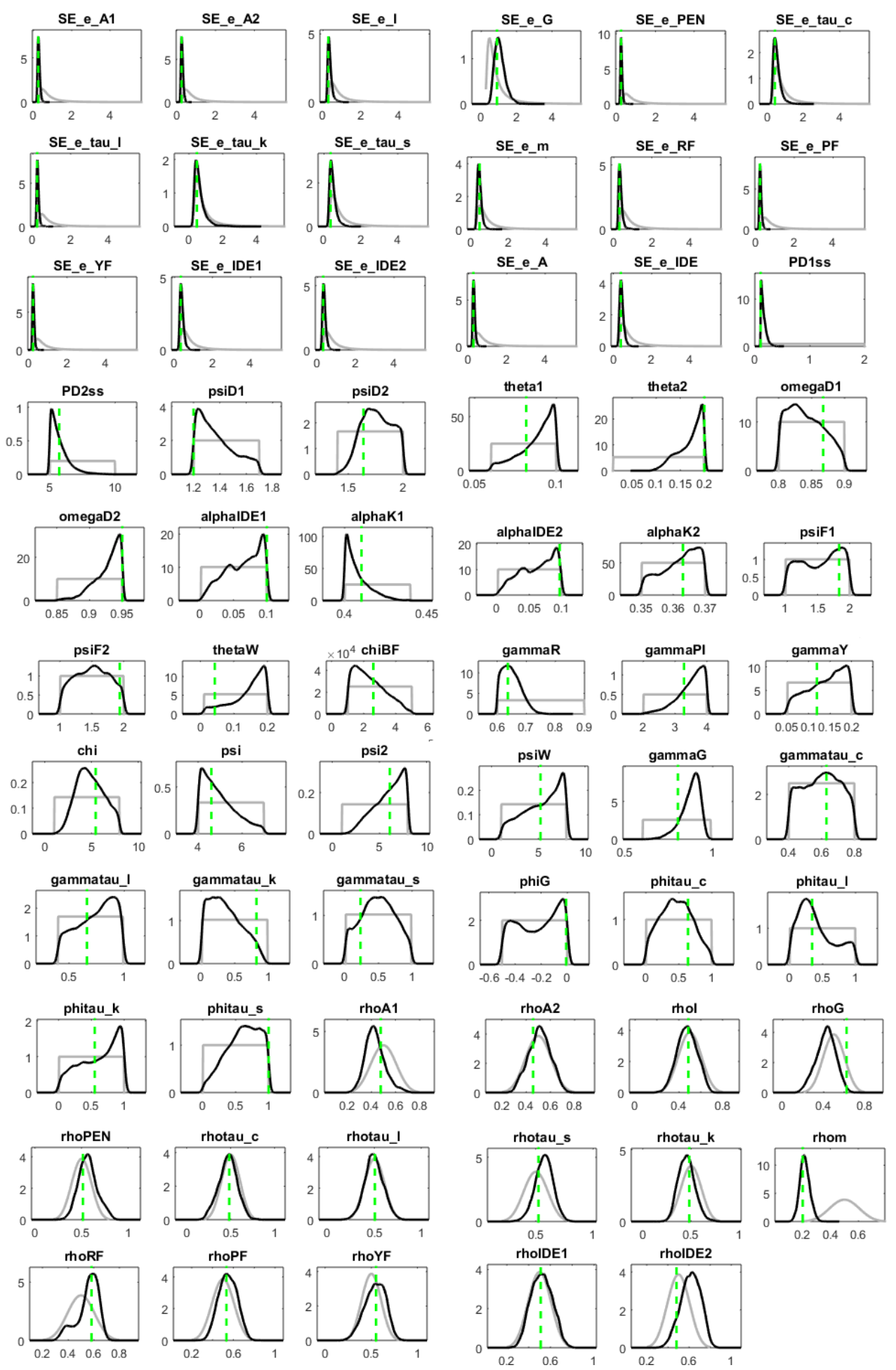

Figure 1. Posterior distribution of the model

Source: Own elaboration.

At this point, it is important to mention that there are two accelerating effects working simultaneously but reduce real output. On one side, the fiscal accelerator, FDI induces an increase in real output but reduces taxes and public debt. This reduces government spending causing a further reduction in real output. On the other side there is a monetary accelerator. The increase in FDI rises real GDP which induces an increase in the price level but rises the domestic interest rate, affecting negatively investment and, as a result, real output. 

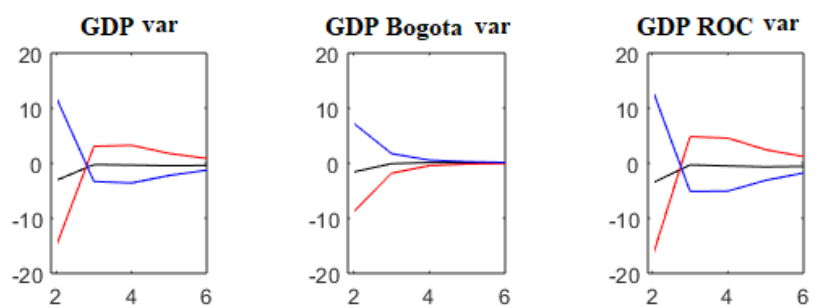

consumption var

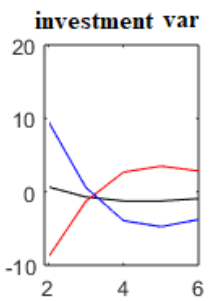

government spending var
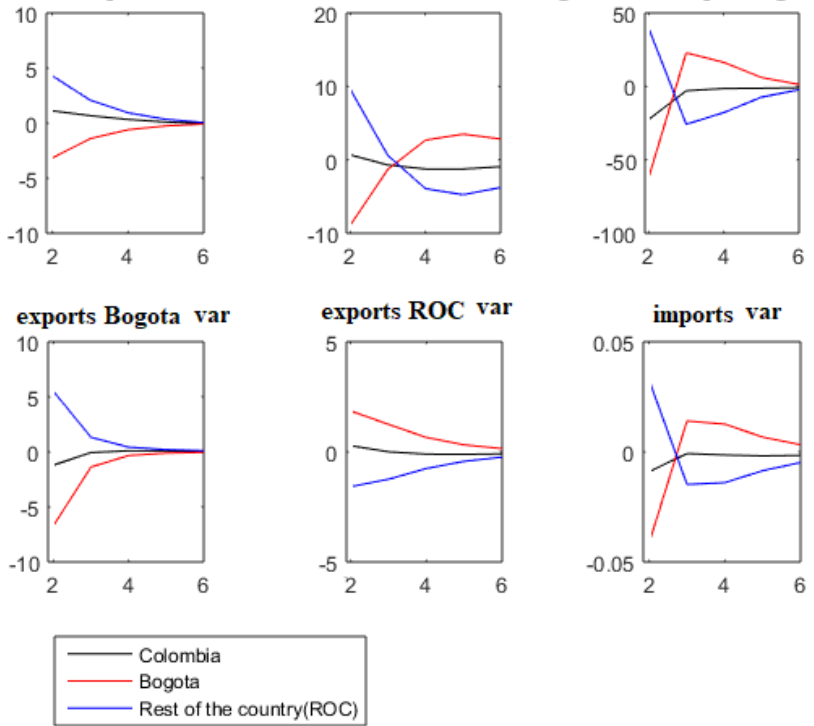

Figure 2. Impulse-response functions for an increase in foreign direct investment (FDI) - aggregate demand variables

Source: Prepared by the authors.
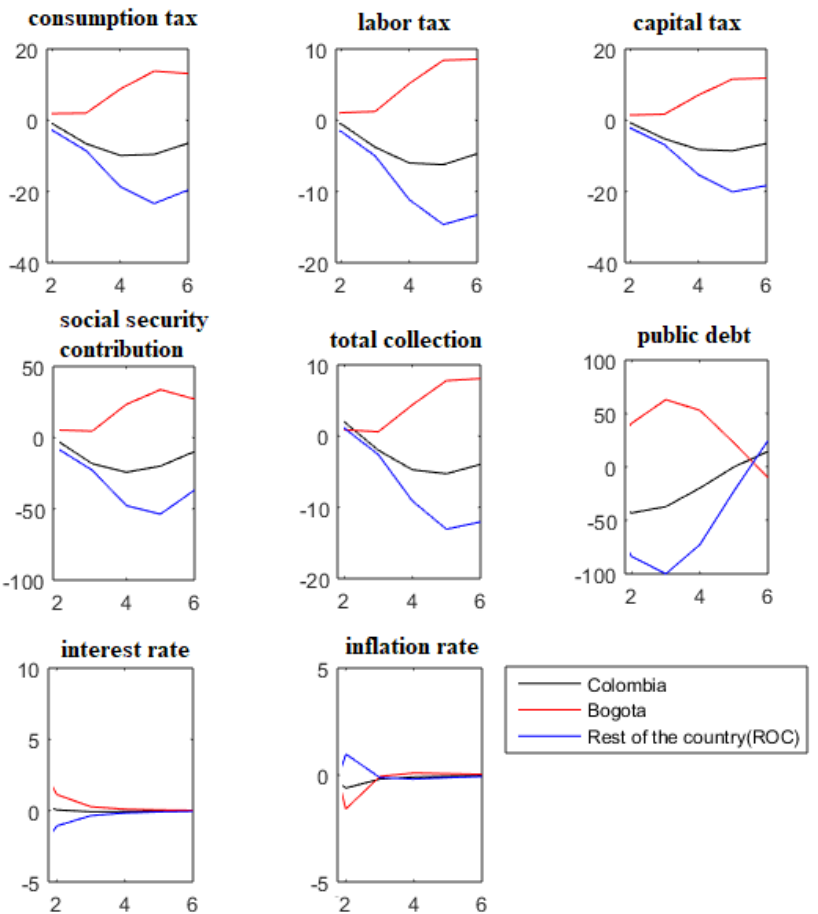

Figure 3. Impulse-response functions for an increase in foreign direct investment (FDI) - fiscal and monetary variables

Source: Prepared by the authors. 


\subsubsection{FDI in ROC}

The $10 \%$ increase in FDI in the rest of the country produces an increase in real output caused by the increase in the capital stocks of both regions but real GDP in the ROC rises more than Bogota GDP. Salaries tend to increase in the ROC but in Bogota wages might fall. Consumption and investment rise as a result of the acceleration principle and the slight reduction of the domestic interest rate, which creates an upward pressure on the price level and an appreciation of the domestic currency. As the economy improves, taxes are lowered which reduces total collection. Then, the Banco de la Republica reacts increasing domestic credit which lowers the interest rate inducing an increase in investment, government spending, and real output.

The fiscal and monetary accelerators in this particular case provoke an increase in aggregate real GDP. Through the fiscal accelerator, the increase in FDI rises real output, reduces tax collections and increases the government debt. These funds serve to increase government spending, which further rises real output. With respect to the monetary accelerator, the increase in FDI, and as a result real GDP, causes inflation to augment. Then, the Banco de la Republica reacts reducing the domestic interest rate, provoking an investment increase, and, as a result, a higher real GDP.
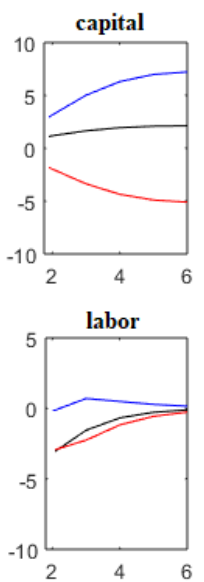

domestic inputs Bogota

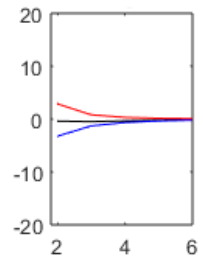

exported inputs ROC
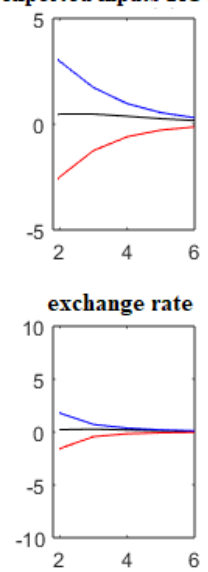
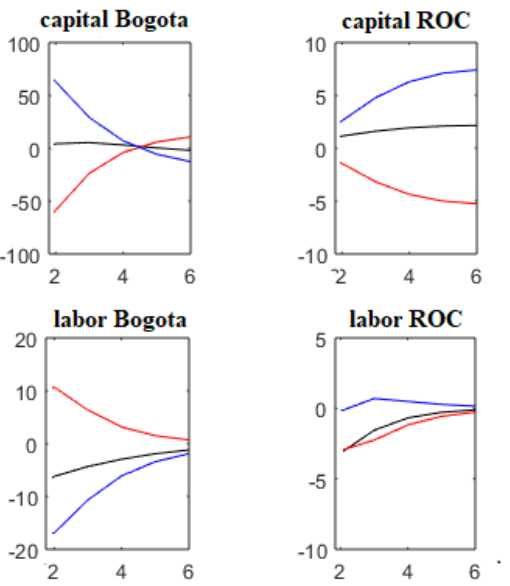

domestic inputs ROC
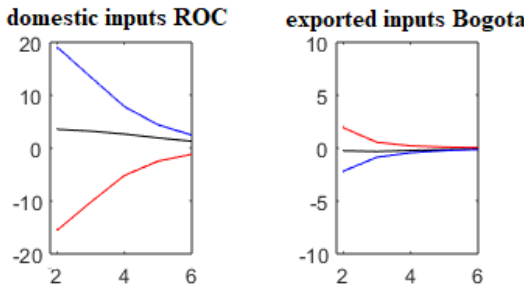

imported inputs Bogota
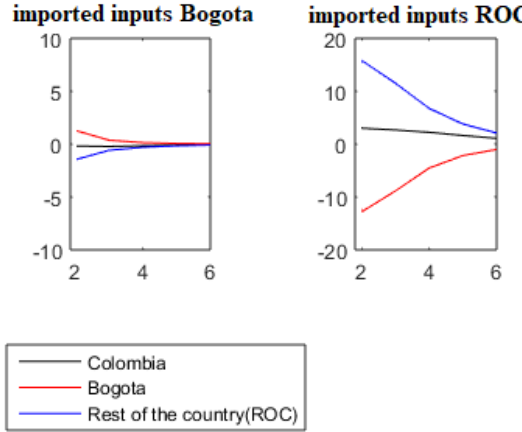

Figure 4. Impulse-response functions for an increase in foreign direct investment (FDI) - other variables 


\subsubsection{Shocks Decomposition}

Figure 5 ahead shows the variance decomposition of real GDP growth rate. Shocks were grouped in categories: fiscal (taxes and government spending), foreign (interest rate, prices and GDP), monetary, productivity, and so on. As we can see, with the exception of years 2003, 2009, 2011, and 2017, output variability is explained in most cases by FDI shocks occurring in Bogota or the ROC. FDI shocks to Bogota tend to explain a larger output variability than do FDI shocks to the ROC, particularly in 2004, 2007-2008, 2010, and 2013. FDI shocks to the ROC dominate during 2005 and 2012. Other shocks that were also important and affected output variability were related to monetary policy in 2007, 2011, and 2014; foreign shocks in 2009, 2011, 2014, and 2015; and fiscal shocks in 2009, 2011, and 2014; and, finally, productivity shocks in 2006 and 2007. Consumer and labor shocks were the least important shocks and do not significantly explain output growth variability at any specific year or period.

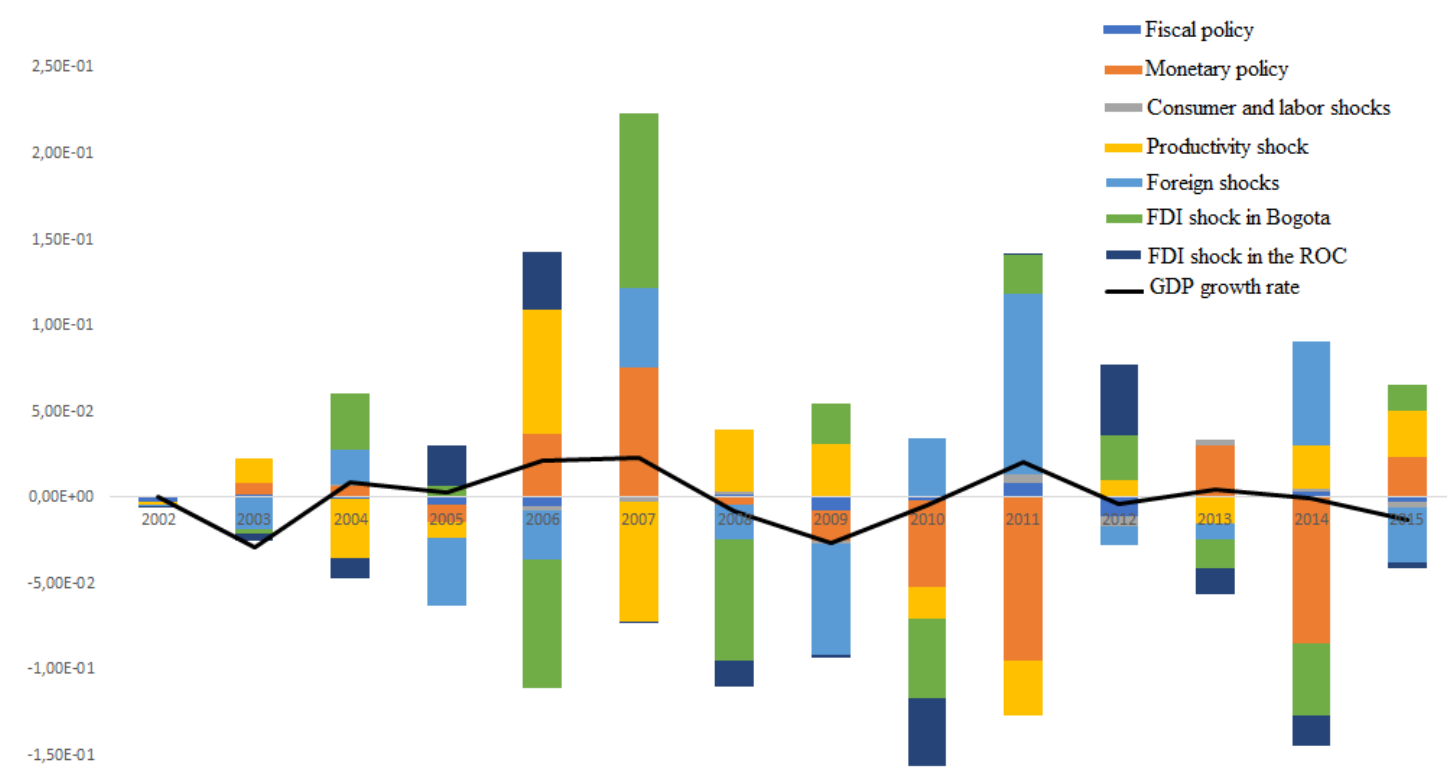

Figure 5. Shock decomposition of GDP growth rate

Source: Prepared by the authors.

\section{Conclusions}

Since early 1990s and after having decided to implement a series of fiscal, monetary, and market reforms and to open the economy to the rest of the world, Colombia, although with small swings, has been growing and becoming an important actor in Latin America. In fact, the creation of the Pacific Alliance and the different free trade agreements signed up until now are proofs of such assertion. Besides, the participation of FDI has increased in an important way when compared to the early years of the 1990s. However, there are no contributions in the literature that studies the effects that FDI may have on the Colombian economy. There are several DSGE models developed by the central bank of Colombia focusing on fiscal analysis but not on FDI. In order to fill the gap in the literature, we have built a DSGE model that considers important features of the Colombian economy, for instance that more than $25 \%$ of its GDP is produced in Bogota. Thus, this will allow us to study the regional microeconomic effects that FDI will have on the two regions that have been considered in our model: Bogota and the rest of the country. We have also assumed that production takes place in both regions and that there are final and intermediate firms. Besides, we have assumed three types of households: Ricardian, Non-Ricardian and non-pensioned and Non-Ricardian-Pensioned, where Ricardian agents exhibit habit formation. Finally, we have also built a foreign sector that set foreign prices for our exports and inputs. This is somewhat medium to large scale model, but it is well fitted to the Colombian economy and consequently the simulated results are important contributions to the understanding of the impacts of FDI.

Empirical results show that the way FDI enters the economy might produce asymmetric results. FDI long run response of real output, inflation, employment, interest rates, and exchange rate tend to return to their steady 
states after 4 to 6 years, independently from the regions where FDI first took place. However, the short run responses to shocks of FDI in Bogota, in the rest of the country, or in the entire country (even distribution of FDI thoughout the country) are asymmetric. This has important implications for economic policy. We have shown that that FDI in the ROC might induce important microeconomic adjustments in labor, capital and goods markets throughout the country, increasing not only the ROC real GDP but also Bogota. As a result, public policy can be directed to specific regions and sectors of the country besides Bogota. The development of physical infrastructure, applying differentiated regional fiscal instruments, and strenghtening political institutions may attract foreign investors that will surely bring their capital to these regions. At the same time, the government might promote innovation and business aspirations to estimulate small and medium size enterprises with domestic capital. Consequently, employment and labor mobility would improve, labor markets will grow and develop, income distribution will improve, and welfare surely will rise.

\section{Acknowledgments}

We want to thank Pontificia Universidad Javeriana - Cali for providing the funds for research visits that we carry out at State University of Ponta Grossa and School of Economics - Getúlio Vargas Foundation, Brazil, and Pontificia Universidad Javeriana - Cali, Colombia

\section{References}

Bernanke, B. S., \& Gertler, M. (1999). Monetary policy and asset price volatility. In Proceedings-Economic Policy Symposium-Jackson Hole (pp. 77-128). Federal Reserve Bank of Kansas City. https://doi.org/10.3386/w7559

Bonaldi, J., Gonzalez, A., \& Rodriguez, D. (2010). Importancia de las rigideces nominales y reales en Colombia: un enfoque de equilibrio general dinámico y estocástico. Borradores de Economía, 591.

Calvo, G. A. (1983). Staggered prices in a utility-maximizing framework. Journal of Monetary Economics, 12(3), 383-398. https://doi.org/10.1016/0304-3932(83)90060-0

Costa-Junior, C. J., Garcia-Cintado, A. C., \& Sampaio, A. V. (2017). Post-2008 Brazilian fiscal policy: An interpretation through the analysis of fiscal multipliers. Estudos Economicos (Sao Paulo), 47(1), 93-124. https://doi.org/10.1590/0101-416147149caa

DANE. (2016). Estadísticas por tema: Cuentas Nacionales (online). Bogotá, D.C., Colombia. Retrieved from http://www.dane.gov.co/index.php/estadisticaspor-tema/cuentas-nacionales.

Díaz, S. O. (2012). A model of rule-of-thumb consumers with nominal price and wage rigidities. Borradores de Economía, 707.

Dixit, A. K., \& Stiglitz, J. E. (1977). Monopolistic competition and optimum product diversity. The American Economic Review, 67(3), 297-308.

Galí, J. (2015). Monetary policy, inflation, and the business cycle: an introduction to the new Keynesian framework and its applications. Princeton and Oxford: Princeton University Press

González, A., Mahadeva, L., Prada, J. D., \& Rodríguez, D. (2011). Policy analysis tool applied to Colombian needs: PATACON model description. Ensayos Sobre Política Económica, 29(66), 222-245. https://doi.org/10.32468/Espe.6606

González, A., Ocampo, S., Rodríguez, D., \& Rodríguez, N. (2011). Asimetrías del empleo y el producto, una aproximación de equilibrio general. Borradores de Economía, 663.

González-Gómez, A., López-Piñeros, M. R., Rodríguez-Niño, N., \& Téllez, S. (2013). Fiscal policy in a small open economy with oil sector and non-ricardian agents. Borradores de Economía, 759. https://doi.org/10.13043/DYS.73.2

Haddad, E. A., Bonet, J., Hewings, G. J., \& Perobelli, F. S. (2008). Efectos regionales de una mayor liberación comercial en Colombia: una estimación con el modelo CEER. Documentos de Trabajo Sobre Economía Regional, 104. Cartagena: Centro de Estudios Económicos Regionales (CEER).

López, M. (2015). Asset price bubbles and monetary policy in a small open economy. Ensayos Sobre Política Económica, 33(77), 93-102. https://doi.org/10.1016/j.espe.2014.11.003

López, M. (2016). Fiscal multipliers, oil revenues and balance sheet effects Borradores de Economía, 976.

Parra-Alvarez, J. C. (2008). Hechos estilizados de la economía colombiana: Fundamentos empíricos para la construcción y evaluación de un modelo DSGE. Borradores de Economía, 509. 
Portafolio. (2014). Alianza del Pacífico lanzará integración de mercados. Portafolio, 12 de junio de 2014. Retrieved from http://www.portafolio.co/economia/integracion-bolsas-valores-alianza-del-pacifico

Rincón-Castro, H., Rodríguez-Guzmán, D. A., Toro-Córdoba, J. H., \& Téllez, S. (2014). Fisco: Modelo fiscal para Colombia. Borradores de Economía, 855.

Schmitt-Grohé, S., \& Uribe, M. (2003). Closing small open economy models. Journal of international Economics, 61(1), 163-185. https://doi.org/10.1016/S0022-1996(02)00056-9

Smets, F., \& Wouters, R. (2007). Shocks and frictions in US business cycles: A Bayesian DSGE approach. American Economic Review, 97(3), 586-606. https://doi.org/10.1257/aer.97.3.586

Solano, C. (2013). La política comercial de Colombia: Del pasado al futuro. Puentes, 14(5), 1-6.

Stiglitz, J. E. (2017). Where Modern Macroeconomics Went Wrong. NBER Working Paper 23795. National Bureau of Economic Research. https://doi.org/10.3386/w23795

U.S. International Trade Commission. (1997). The dynamic effects of trade liberalization: An empirical analysis. Investigation No. 332-275, Publication 3069: Washington, D.C.

Valencia, O., Osorio, D., \& Garay, P. (2017). The role of capital requirements and credit composition in the transmission of macroeconomic and financial shocks. Ensayos Sobre Política Económica, 35(84), 203-221. https://doi.org/10.1016/j.espe.2017.09.001

Note

Note 1. For information on the Bayesian estimation, consult: De Jong and Dave, 2007; and Canova, 2007.

\section{Copyrights}

Copyright for this article is retained by the author(s), with first publication rights granted to the journal.

This is an open-access article distributed under the terms and conditions of the Creative Commons Attribution license (http://creativecommons.org/licenses/by/4.0/). 